\title{
Pemanfaatan Karotenoid Minyak Sawit Merah untuk Mendukung Penanggulangan Masalah Kekurangan Vitamin A di Indonesia
}

\section{Utilization of Red Palm Oil Carotenoids to Support the Prevention of Vitamin A Deficiency Problem in Indonesia}

\author{
Risnawati Dwi Maryuningsih¹, Budi Nurtama², dan Nur Wulandarii, ${ }^{2,}$ \\ ${ }^{1}$ Program Studi Ilmu Pangan, Sekolah Pascasarjana, IPB University, PO BOX 220, Bogor 16002, Jawa \\ Barat, Indonesia \\ ${ }^{2}$ Departemen IImu dan Teknologi Pangan, FakultasTeknologi Pertanian, IPB University, PO BOX 220, Bogor \\ 16002, Jawa Barat, Indonesia \\ ${ }^{3}$ Southeast Asian Food and Agricultural Science and Technology (SEAFAST Center), IPB University, \\ Indonesia \\ E-mail: wulandari_n@apps.ipb.ac
}

Diterima: 25 Januari 2020

Revisi: 24 Februari 2021

Disetujui: 29 Maret 2021

\begin{abstract}
ABSTRAK
Kekurangan vitamin A (KVA) merupakan kondisi gangguan kesehatan akibat tidak terpenuhinya kebutuhan vitamin A di dalam tubuh. KVA merupakan defisiensi mikronutrien yang paling banyak terjadi di negara berkembang, termasuk di Indonesia. Asupan vitamin A yang tidak tercukupi dapat meningkatkan prevalensi terjadinya berbagai jenis penyakit yang dapat mengganggu berbagai fungsi organ tubuh. Pemenuhan vitamin A melalui asupan pangan hewani sulit dijangkau oleh masyarakat berpenghasilan rendah sehingga diperlukan strategi pemenuhan vitamin A melalui pangan nabati yang dapat dijadikan sebagai sumber provitamin A. Minyak sawit merah merupakan produk hasil pemurnian minyak sawit dengan tetap mempertahankan kandungan karotenoidnya yang berperan penting sebagai sumber provitamin A alami. Pemanfaatan minyak sawit merah dalam pangan khususnya sebagai bahan fortifikan pangan dapat meningkatkan status vitamin $A$ dan berperan dalam menanggulangi permasalahan kekurangan vitamin $A$. Artikel ini membahas permasalahan kekurangan vitamin A di Indonesia dan strategi penanggulangannya, potensi minyak sawit merah sebagai sumber provitamin A alami, serta strategi pemanfaatan minyak sawit merah sebagai fortifikan pangan dan suplemen kesehatan.
\end{abstract}

kata kunci: fortifikan, minyak sawit merah, provitamin $\mathrm{A}$, suplemen, vitamin $\mathrm{A}$

\section{ABSTRACT}

Vitamin A deficiency is a health problem due to unfulfilled vitamin A requirement in the body. It is the most common micronutrient deficiency in developing countries, including Indonesia. Inadequate intake of vitamin A can increase the prevalence of various types of diseases that can affect body organs' various functions. Fulfillment of vitamin A through animal food intake is difficult to achieve for people with lowincome. A strategy to fulfill vitamin A requirement through plant based food as a source of provitamin $A$ is needed. Red palm oil is a product made from refined palm oil while maintaining its carotenoid content as a natural source of provitamin $A$. The use of red palm oil in food, mostly as a food fortification material, can improve vitamin A status and play a role in overcoming vitamin A deficiency. This article discusses vitamin A deficiency in Indonesia and its countermeasures strategies, the potential of red palm oil as a source of natural provitamin $A$, and strategies for using red palm oil as food fortification material and health supplement.

keywords: fortified, red palm oil, provitamin A, supplement, vitamin A

\section{PENDAHULUAN}

ekurangan vitamin A (KVA) merupakan kondisi gangguan kesehatan akibat tidak terpenuhinya kebutuhan vitamin A di dalam tubuh. KVA termasuk defisiensi mikronutrien yang paling banyak terjadi pada anak-anak di berbagai belahan dunia, terutama yang tinggal di negara berkembang. Vitamin A tidak dapat dihasilkan oleh tubuh sehingga harus diperoleh 
melalui asupan pangan harian, baik melalui pangan hewani sebagai sumber preformed vitamin $A$, maupun pangan nabati sebagai sumber provitamin A. Angka kecukupan vitamin A yang dianjurkan yaitu sekitar 400-600 RE (retinol equivalents) per orang per hari (Kemenkes, 2019).

Data WHO menunjukkan bahwa KVA memengaruhi sekitar 85 juta (7 persen) anak usia sekolah dan merupakan masalah kesehatan pada lebih dari setengah negara di dunia, terutama di Afrika dan Asia Tenggara. WHO memperkirakan 250.000 hingga 500.000 anak yang menderita KVA mengalami kebutaan setiap tahunnya. Setengah dari mereka meninggal dunia dalam kurun waktu 12 bulan akibat kehilangan penglihatan (WHO, 2011; SHN, 2020). Sementara itu di Indonesia, masalah KVA dapat diibaratkan sebagai fenomena "gunung es", yang hanya sedikit tampak di permukaan, namun KVA secara subklinis masih banyak ditemui (Depkes, 2003; Kemenkes, 2015). Di Indonesia, 1 dari 2 balita kemungkinan besar mengalami KVA. Riskesdas (2018) melaporkan bahwa hanya sekitar 53,5 persen anak usia 6-59 bulan dalam 12 bulan terakhir yang kebutuhannya terhadap vitamin $\mathrm{A}$ terpenuhi melalui pemberian kapsul vitamin A.

KVA dapat menyebabkan berbagai penyakit yang tergolong sebagai nutrition related diseases, menyerang berbagai macam anatomi dan fungsi dari organ tubuh, seperti menurunkan sistem kekebalan tubuh, menurunkan epitelisme selsel kulit, menyebabkan terjadinya gagal tumbuh, serta risiko tinggi terhadap xerophthalmia dan kebutaan (Depkes, 2003). Asupan vitaminA pada anak yang tidak tercukupi dapat meningkatkan prevalensi terhadap stunting (badan pendek/ kerdil), underweight (berat badan rendah), dan wasting (badan kurus) lebih tinggi dibandingkan anak yang memperoleh vitamin A secara cukup. Riskesdas (2018) melaporkan data prevalensi di Indonesia untuk stunting sebesar 30,8 persen, underweight sebesar 17,7 persen, dan wasting sebesar 10,2 persen. KVA juga dapat memicu dampak yang lebih serius yaitu dapat menyebabkan gangguan penglihatan (rabun senja) dan meningkatkan risiko penyakit serta mortalitas akibat infeksi seperti campak dan diare pada usia anak-anak (WHO, 2011).
Makanan sehari-hari yang dapat dijadikan sebagai sumber preformed vitamin A berasal dari pangan hewani di antaranya hati, ikan, telur, susu, dan keju (Depkes 2003; WHO 2009). Namun, bagi masyarakat berpenghasilan rendah, pemenuhan vitamin A melalui pangan hewani tersebut cukup sulit karena harganya yang relatif mahal. Konsumsi pangan yang kurang dari 80 persen angka kecukupan gizi (AKG) secara berkepanjangan, secara umum disebabkan oleh kemiskinan, yaitu saat keluarga tidak mampu memberikan makanan yang cukup (Depkes, 2003).

Beberapa upaya penanggulangan KVA telah dilakukan di Indonesia, antara lain melalui pelaksanaan program suplementasi vitamin A dosis tinggi dan program fortifikasi minyak goreng sawit (MGS) komersial. Namun, masih terdapat sekitar 46,4 persen anak usia 6-59 bulan pada setiap provinsi di Indonesia yang belum menerima kapsul vitamin A (Riskesdas, 2018). Di samping itu, penerapan program fortifikasi MGS komersial masih terkendala polemik terkait vitamin A sintetis sebagai fortifikan (Hasibuan dan Siahaan, 2014). Oleh karena itu, pelaksanaan kedua program tersebut masih belum efektif untuk menanggulangi KVA secara keseluruhan. Strategi lain yang dianggap potensial untuk dilaksanakan yaitu dengan memanfaatkan langsung minyak sawit sebagai fortifikan provitamin A alami. Hal ini didukung oleh potensi minyak sawit di Indonesia yang produksinya pada tahun 2019 telah mencapai 51,8 juta ton (GAPKI, 2020).

Minyak sawit secara alami mengandung kadar karotenoid yang tinggi, khususnya beta karoten yang merupakan provitamin A. Minyak sawit yang diproses secara khusus dapat mempertahankan kadar karotenoidnya tetap tinggi dan menghasilkan produk yang dikenal sebagai minyak sawit merah (MSM). Strategi pemanfaatan karotenoid minyak sawit ini perlu dikembangkan lebih lanjut, baik melalui pengembangan produk yang masih dapat mempertahankan kandungan karotenoidnya agar tetap tinggi, maupun melalui pengembangan proses aplikasinya pada berbagai produk pangan. Tulisan ini akan memberikan gambaran tentang potensi MSM dalam mendukung upaya penanggulangan KVA, serta strategi pemanfaatan MSM khususnya sebagai fortifikan pangan dan suplemen kesehatan. 


\section{MASALAH KEKURANGAN VITAMIN A DAN UPAYA PENANGGULANGANNYA}

Prevalensi KVA di dunia menjangkit 190 juta anak usia pra sekolah (33 persen) dan 19 juta wanita hamil (15 persen) (WHO, 2009; Rice dan Burns, 2010). Penelitian WHO pada tahun 1992 menunjukkan bahwa dari 20 juta balita di Indonesia yang berumur 6 bulan hingga 5 tahun, setengahnya menderita KVA subklinis (serum retinol $<20 \mu \mathrm{g} / \mathrm{dl}$ ). Pada tahun 1994 permasalahan KVA di Indonesia berangsur membaik yang ditandai dengan diraihnya penghargaan "Hellen Keller Award" karena mampu menurunkan prevalensi xerophthalmia sampai 0,3 persen. Namun, pada pertengahan tahun 1997 terjadi krisis ekonomi di Indonesia yang mengakibatkan masalah KVA muncul kembali (Depkes, 2003). Indonesia menjadi salah satu negara di Asia Tenggara dengan tingkat pemenuhan vitamin A yang tergolong rendah (Adawiah, 2012). Pada tahun 2010, di Indonesia terdapat sekitar 10 juta balita mengalami KVA (Tsaqqofa, 2010).

Perhatian serius terhadap penanggulangan dampak KVA meningkat seiring dengan semakin meningkatnya jumlah anak Indonesia penderita xerophthalmia ringan (rabun senja dan bercak bitot) yang meninggal dunia. Pencegahan terhadap KVA diperkirakan dapat mengurangi kematian anak-anak di Indonesia sekitar 16 persen (Sommer, dkk., 1983). Selain pada kelompok usia balita dan anak-anak, kasus KVA juga dapat ditemui pada kelompok usia lainnya dengan data yang terbatas. Kondisi KVA di Indonesia pada semua kelompok usia diuraikan oleh Jati, dkk. (2012) yaitu pada kelompok anakanak sebesar 57 persen, diikuti oleh dewasa muda sebesar 29 persen, dan dewasa sebesar 16 persen.

Program suplementasi vitamin A dosis tinggi dimulai sejak tahun 1990-an sebagai upaya untuk menanggulangi masalah KVA. Lebih dari 80 negara menerapkan program tersebut. Target program tersebut adalah anakanak usia 6 hingga 59 bulan melalui program nasional semi-tahunan, termasuk di Indonesia yang dilakukan setiap bulan Februari dan Agustus. Pada tahun 2015-2016, cakupan suplementasi vitamin A mengalami penurunan lebih dari 50 persen jika dibandingkan dengan tahun sebelumnya. Hal ini mengakibatkan anakanak berusia 6-59 bulan tidak terlindungi dari KVA dengan jumlah lebih dari tiga kali lipat dibandingkan dengan negara-negara dengan tingkat kematian tinggi. Selama periode tersebut diperkirakan terjadi peningkatan penderita dari 19 juta menjadi 62 juta (UNICEF, 2019). Palmer, dkk. (2012) menilai bahwa suplementasi vitamin A hanya mampu meningkatkan status vitamin $A$ selama tiga bulan pada anak dengan pola diet buruk. Secara keseluruhan, aplikasi suplemen vitamin A hanya sedikit berpengaruh terhadap pertumbuhan linier dan tidak berpengaruh terhadap pertumbuhan ponderal, serta tidak memiliki efek secara menyeluruh terhadap mortalitas yang disebabkan oleh KVA.

Pemberian suplemen vitamin A secara konsisten menjadi tantangan yang harus dihadapi oleh banyak negara karena membutuhkan dukungan publik, pendanaan yang stabil, dan kemitraan yang efektif. Selain itu, program tersebut juga dihadapkan dengan masalah keterbatasan target kelompok usia sehingga dinilai tidak efektif dan relevan. Terkait hal tersebut, Mason, dkk. (2014) menyarankan pergeseran kebijakan penurunan KVA melalui intervensi lain yaitu dari suplementasi menjadi fortifikasi vitamin A. Penerapan program fortifikasi vitamin A di Indonesia ditetapkan oleh pemerintah melalui kebijakan wajib fortifikasi vitamin A di MGS komersial yang dicantumkan pada SNI 7709:2012 dan kemudian direvisi menjadi SNI 7709:2019 yang mengharuskan MGS keluaran pabrik mengandung vitamin $A$ dengan kadar $45 \mathrm{lU} / \mathrm{g}$.

Pemberlakuan SNI MGS secara wajib tertulis pada Peraturan Menteri Perindustrian RI No. 46 Tahun 2019 (Kemenperin, 2019). Kebijakan tersebut menargetkan seluruh lapisan masyarakat konsumen agar dapat memenuhi kebutuhan vitamin A yang belum tercukupi dari makanan sehari-hari. Namun, hal ini masih terus dikritisi oleh para produsen minyak nabati di Indonesia. Mereka menolak mandatori fortifikasi vitamin A pada minyak goreng karena vitamin A sintetik yang dipakai masih harus diimpor dari negara lain. Jenis vitamin A yang sering ditambahkan pada minyak adalah vitamin $A$ asetat dan palmitat yang memiliki kelemahan utama yaitu harus diimpor dari luar negeri dan 
biayanya relatif mahal (Hasibuan dan Siahaan, 2014). Jika fortifikasi vitamin A menjadi wajib, akibatnya Indonesia bergantung kepada impor vitamin A sintetik dan setiap tahun akan membuang devisa ke luar negeri.

Dengan kewajiban fortifikasi vitamin $A$, biaya produksi MGS akan meningkat sehingga harganya menjadi lebih tinggi. Di samping itu, fortifikasi vitamin A pada MGS dianggap tidak efektif terkait stabilitas dan retensi vitamin A pada saat proses penggorengan. Dengan demikian, strategi fortifikasi vitamin A sintetik pada MGS komersial masih menghadapi polemik dan berbagai kendala, baik yang muncul dari sektor industri dan ekonomi, maupun terkait aspek stabilitasnya. Oleh karena itu, diperlukan strategi lain yang mempertimbangkan efektivitas fortifikasi vitamin A tersebut di tingkat industri maupun di masyarakat.

\section{KAROTENOID SEBAGAI SUMBER VITAMIN A}

Karotenoid merupakan pigmen organik yang memberikan warna oranye kemerahan pada minyak sawit dan merupakan bagian senyawa fungsional utama yang bermanfaat bagi kesehatan tubuh. Karotenoid termasuk hidrokarbon tidak jenuh karena memiliki ikatan rangkap di antara dua atom karbon yang terkonjugasi dan umumnya berbentuk trans (Nokkaew, dkk., 2019). Meskipun terukur sebagai asam lemak tidak jenuh, kandungan karotenoid beserta tokoferol dan tokotrienol berfungsi sebagai antioksidan kuat dan menjadikan minyak sawit sebagai minyak nabati yang direkomendasikan bagi kesehatan (Catanzaro, dkk., 2016). Karotenoid berperan sebagai antioksidan dan antikarsinogenik yang sangat kuat karena kemampuannya untuk memadamkan oksigen radikal atau molekul tunggal. Karotenoid pada MSM merupakan sumber provitamin A yang paling efisien digunakan untuk membantu menanggulangi masalah KVA (Manorama, dkk. 2014). Sluijs, dkk. (2015) menambahkan bahwa asupan karotenoid mampu menurunkan risiko diabetes mellitus sebesar 16 persen.

Jenis karotenonid yang berperan sebagai provitamin A adalah beta karoten. Asupan beta karoten dapat membantu menyeimbangkan kebutuhan retinol yang belum terpenuhi karena beta karoten dalam usus akan dikonversi menjadi 2 molekul vitamin A (Grune, dkk., 2010). Aktivitas provitamin A terjadi secara enzimatik di mukosa intestinal. Perubahan retinal menjadi retinol dibantu oleh enzim dioksigenase (Rahmadi, dkk., 2016). Di dalam enterosit, beta karoten akan diubah menjadi 2 retinal dan dikonversi menjadi retinol dengan bantuan retinal reduktase. Beta karoten yang dikonsumsi akan diabsorbsi yang mana sepertiganya akan diangkut oleh kilomikron dan sisanya akan dieksresikan. Setengah dari beta karoten yang diangkut, diubah menjadi retinol dalam mukosa usus dengan bantuan enzim dari sitosol sel usus.

Jumlah total vitamin A dinyatakan dalam mikrogram retinol equivalents (RE). Nagendran, dkk. (2000) menyatakan bahwa 1 RE setara dengan $1 \mu \mathrm{g}$ retinol atau $6 \mu \mathrm{g}$ beta karoten atau $12 \mu \mathrm{g}$ provitamin A karotenoid. Rata-rata angka kecukupan gizi (AKG) vitamin A yang dianjurkan untuk masyarakat umum di Indonesia ditetapkan $600 \mathrm{RE}$ atau setara dengan $3600 \mu \mathrm{g}$ beta karoten sesuai SK Menteri Kesehatan RI No. 28 Tahun 2019. Menurut FDA (2009), suatu pangan dapat diklaim sebagai sumber karotenoid yang baik apabila memenuhi 10 persen atau lebih AKG vitamin A per takaran saji. Dengan demikian, kadar minimal beta karoten yang harus dipenuhi dalam suatu produk adalah $360 \mu \mathrm{g}$ beta karoten per takaran saji (Yuliasari, dkk., 2014).

Peranan beta karoten sebagai sumber provitamin A penting dalam mendukung fungsi tubuh di antaranya yaitu membantu pertumbuhan dan perkembangan normal, fungsi imun, dan penglihatan (Grune, dkk., 2010). IOM (2001) menambahkan bahwa mengonsumsi 3-6 mg/ hari beta karoten (3600-6000 $\mu \mathrm{g} /$ hari) dapat mengurangi risiko terkena penyakit kronis.

\section{POTENSI MINYAK SAWIT MERAH SEBAGAI SUMBER PROVITAMIN A}

Minyak sawit mengandung mikronutrien yang paling dominan dan unggul berupa karotenoid. Kandungan karotenoid pada minyak sawit berkisar antara 600-1000 ppm yang terdiri dari alfa karoten $\pm 36,2$ persen, beta karoten $\pm 54,4$ persen, gamma karoten $\pm 3,3$ persen, likopen $\pm 3,8$ persen, dan santofil $\pm 2,2$ persen (Naibaho, 1990). Beta karoten merupakan jenis 
utama kelompok senyawa karotenoid yang terdapat dalam minyak sawit yang berperan sebagai prekursor vitamin A.

Proses pengolahan minyak sawit menjadi minyak goreng sawit komersial di industri pangan pada umumnya melalui serangkaian tahap pemurnian, yaitu pemisahan gum (degumming), netralisasi (deasidifikasi), pemucatan (bleaching), dan deodorisasi. Proses bleaching dilakukan pada suhu $90-105^{\circ} \mathrm{C}$ menggunakan bleaching earth 1-2 persen dan deodorisasi pada 240$270^{\circ} \mathrm{C}$ (Basiron, dkk., 2000). Bleaching earth dan tingginya suhu deodorisasi menyebabkan perubahan warna minyak dari oranye kemerahan menjadi kuning pucat yang menandakan terdegradasinya komponen karotenoid. Kisaran karotenoid yang ada di MGS yaitu hanya sekitar 1-3 ppm dan warnanya menjadi maksimum 3 red, padahal rerata warna awal minyak sawit adalah 20 red (Hasibuan dan Siahaan, 2014). Hampir seluruh industri MGS komersial di Indonesia menerapkan serangkaian proses tersebut untuk menghilangkan komponen karotenoid. Hal tersebut untuk memenuhi permintaan konsumen Indonesia yang menginginkan MGS yang jernih dan rasanya netral.

Di sisi lain, dengan diketahuinya potensi fungsional karotenoid pada MSM bagi kesehatan, pengembangan produk MSM menjadi sangat potensial. Modifikasi proses produksi yang membedakan MSM dengan MGS komersial yaitu tidak dilakukannya tahap bleaching (pemucatan) dan suhu deodorisasi yang lebih rendah. Beta karoten dalam MSM dapat dipertahankan dan dikonversi menjadi retinol, serta disimpan di dalam hati untuk membantu memenuhi kebutuhan vitamin $A$ (Loganathan, dkk., 2017). Beta karoten dalam MSM memiliki bioavailibilitas yang lebih baik dibandingkan dengan suplemen vitamin A. Hasil penelitian Sommerburg, dkk. (2015) menyatakan bahwa terdapat peningkatan kadar beta karoten dan retinol dalam plasma menggunakan suplementasi MSM dengan dosis beta karoten sedikitnya $1,5 \mathrm{mg}$ total per hari (berkisar 0,02 hingga $0,05 \mathrm{mg} / \mathrm{kg}$ berat badan).

MSM efektif dalam mempertahankan kadar serum retinol sebagai vitamin A pada kelompok yang rentan mengalami KVA (Manorama, 2014). Selain itu, konsumsi minyak sawit pada jumlah yang cukup, sepenuhnya aman dan tidak toksik (Koushki, dkk., 2015). MSM diperkirakan memiliki 15 kali lebih banyak retinol (provitamin A) daripada wortel, 300 kali lebih banyak daripada tomat, dan 44 kali lebih banyak daripada sayuran hijau. Menurut Loganathan, dkk. (2017), $100 \mathrm{~g} \mathrm{MSM} \mathrm{mengandung} 7000$ mg RE.

Kandungan karotenoid pada MSM secara alami larut dalam lemak sehingga memiliki bioavailabilitas yang lebih tinggi dibandingkan sumber lain (Manorama, 2014). Konsumsi MSM yang kaya kandungan karotenoid diharapkan dapat memenuhi kebutuhan konsumsi harian vitamin $A$. AKG untuk memenuhi kebutuhan vitamin A menurut IOM (2001) dapat dilihat pada Tabel 1.

\section{STRATEGI PEMANFAATAN MINYAK SAWIT MERAH SEBAGAI FORTIFIKAN PANGAN DAN SUPLEMEN KESEHATAN}

Pemanfaatan kandungan karotenoid minyak sawit sebagai sumber provitamin A alami, baik yang diaplikasikan sebagai fortifikan bahan pangan maupun sebagai suplemen kesehatan, telah cukup lama digali oleh peneliti Indonesia pada beberapa tahun terakhir [Marliyati, dkk. (2010); Andarwulan, dkk. (2014); Rahmadi, dkk. (2016); Robiyansyah, dkk. (2017); dan Agustina, dkk. (2018)]. Hasil pemurnian minyak sawit

Tabel 1. Angka Kecukupan Gizi (AKG) untuk Vitamin $A$

\begin{tabular}{lccc}
\hline \multicolumn{1}{c}{ Kategori } & Usia & AKG VA $(\boldsymbol{\mu g}$ RE) & Rekomendasi Asupan MSM (g) \\
\hline Bayi & $0-12$ bulan & $400-500$ & $5,7-7,1$ \\
Anak-anak & $1-8$ tahun & $300-400$ & $4,3-5,7$ \\
Dewasa & & & \\
$\quad$ Pria & $9-70$ tahun & $600-900$ & $8,6-12,9$ \\
$\quad$ Wanita & $9-70$ tahun & $600-700$ & $8,6-10$ \\
Ibu hamil & $14-50$ tahun & $750-770$ & $10,7-11$ \\
Ibu menyusui & $14-50$ tahun & $1200-1300$ & $17,1-18,6$ \\
\hline
\end{tabular}

Sumber: IOM (2001) 
dengan tetap mempertahankan kandungan karotenoidnya dikenal sebagai minyak sawit merah (MSM). Potensi MSM untuk dijadikan sebagai bahan fortifikan vitamin A alami dalam memenuhi kebutuhan vitamin A diharapkan dapat berkontribusi terhadap penanggulangan masalah KVA.

Penelitian mengenai beta karoten dari MSM sebagai sumber vitamin A lebih banyak berfokus kepada penggunaan yang tidak terkait dengan proses penggorengan (Martianto, dkk., 2018). Sifat karotenoid yang kurang tahan suhu tinggi serta mudah teroksidasi, menyebabkan MSM kurang sesuai bila diaplikasikan menjadi minyak goreng. Terdapat beberapa kelemahan apabila MSM digunakan sebagai fortifikan dalam MGS komersial. Kelemahan tersebut di antaranya mengubah warna minyak, retensinya relatif lebih rendah pada pemanasan dibandingkan vitamin A sintetik, serta senyawa hasil degradasi pada MGS dengan fortifikan MSM relatif lebih banyak dan tinggi dibandingkan dengan fortifikan vitamin A sintetik (Hasibuan dan Siahaan, 2014).

Degradasi karotenoid dapat terlihat secara makroskopis oleh hilangnya warna yang lebih cepat seiring dengan peningkatan suhu. Semakin tinggi suhu dan lama waktu pemanasan akan menurunkan kandungan beta karoten (Budiyanto, dkk., 2010). Souganidis, dkk. (2013) menyatakan bahwa proses penggorengan berulang akan mengurangi sifat antioksidan beta karoten secara drastis. Selain itu, trans beta karoten yang terdapat dalam minyak akan terdegradasi menjadi 13 cis dan 9 cis beta karoten. Degradasi beta karoten akan menyebabkan minyak berubah menjadi berwarna keabuan dan menghitam.

Faktor-faktor yang memengaruhi tingkat sensitivitas karotenoid adalah oksigen, suhu, cahaya, dan oksidasi. Oleh karena itu, untuk mempertahankan kandungan beta karoten, pemrosesan menggunakan suhu rendah dalam waktu lama lebih dianjurkan dibandingkan pemrosesan dengan suhu tinggi dalam waktu singkat (Koushki, dkk., 2015). Dengan mempertimbangkan hal tersebut, pemanfaatan MSM sebagai sumber provitamin A alami sebaiknya dilakukan melalui penggunaannya dalam formulasi pangan fungsional.
Terdapat dua strategi yang dapat digunakan untuk memanfaatkan karotenoid dari MSM. Strategi pertama yaitu dengan diaplikasikan dalam produk pangan siap santap atau sebagai fortifikan, dan strategi kedua yaitu digunakan sebagai suplemen kesehatan.

\subsection{Aplikasi MSM sebagai Fortifikan pada Produk Pangan}

Berdasarkan Peraturan Kepala BPOM No. 13 Tahun 2016 tentang Pengawasan Klaim pada Label dan Iklan Pangan Olahan, suatu pangan dikatakan sebagai "sumber vitamin" jika memenuhi 15 persen acuan label gizi (ALG) per $100 \mathrm{~g}$ dalam bentuk padat dan dikatakan "tinggi vitamin" jika memenuhi 30 persen ALG per 100 $\mathrm{g}$ dalam bentuk padat. Kelompok usia umum berdasarkan ALG mempunyai kecukupan vitamin A sebesar $600 \mu \mathrm{g} /$ hari (BPOM, 2016) yang mana setiap $1 \mu \mathrm{g}$ RE vitamin A setara dengan $6 \mu \mathrm{g}$ beta karoten sehingga kecukupan beta karoten untuk kelompok umum adalah $3600 \mu \mathrm{g} /$ hari. Penelitian terkait aplikasi MSM sebagai fortifikan produk pangan dalam upaya memenuhi kebutuhan vitamin $A$ tersaji pada Tabel 2.

MSM sebagai bahan fortifikan dapat diaplikasikan di berbagai produk pangan komersial, mulai dari skala kecil (home industry) hingga skala besar (pabrikan) yang dikonsumsi oleh berbagai kalangan konsumen. Fortifikasi MSM dalam berbagai jenis produk pangan olahan yang sering dijumpai dan dikonsumsi sehari-hari bertujuan agar produk dapat menjangkau beragam target, baik dari berbagai kelompok usia maupun status ekonomi yang berbeda. MSM yang diaplikasikan sebagai bahan fortifikan produk pangan olahan dapat diklaim sebagai sumber karotenoid yang baik dan dapat berkontribusi terhadap pemenuhan AKG vitamin A sehari-hari karena dapat memenuhi 10 persen atau lebih AKG vitamin A per takaran saji sesuai yang ditetapkan oleh FDA (FDA, 2009).

Pemanfaatan fortifikan MSM dalam berbagai jenis pangan olahan akan menghasilkan pangan fungsional yang banyak dilirik oleh konsumen seiring dengan semakin meningkatnya kesadaran untuk hidup sehat dan tren makanan sehat. Keterbatasan MSM dari segi warna menjadi pertimbangan penting pada tahap formulasi produk, sekaligus dapat menjadikan 
Tabel 2. Aplikasi MSM sebagai Fortifikan pada Produk Pangan

\begin{tabular}{|c|c|c|c|c|c|}
\hline Produk & $\begin{array}{c}\text { Beta- } \\
\text { karoten } \\
(\mathrm{mg} / \mathrm{kg})\end{array}$ & $\begin{array}{l}\text { Vitamin A } \\
\text { (RE/100 } \\
\text { g) }\end{array}$ & $\begin{array}{l}\text { Takaran } \\
\text { saji (g) }\end{array}$ & $\%$ ALG & Referensi \\
\hline $\begin{array}{l}\text { Susu bubuk } \\
\text { rekombinasi }\end{array}$ & 6,6 & 1,1 & 100 & 18,33 & $\begin{array}{l}\text { Marsono, dkk. } \\
(2007)\end{array}$ \\
\hline Mi instan & 76,42 & 12,74 & 50 & 106,17 & Marliyati, dkk. (2010) \\
\hline $\begin{array}{l}\text { Gel MSM ditambahkan } \\
\text { ke minuman }\end{array}$ & 70 & 11,67 & 250 & $19,44-38,89$ & Astuti (2010) \\
\hline $\begin{array}{l}\text { Margarin MSM pada } \\
\text { pound cake \& roti } \\
\text { manis }\end{array}$ & 98,17 & 16,36 & - & - & $\begin{array}{l}\text { Andarwulan, dkk. } \\
(2014)\end{array}$ \\
\hline $\begin{array}{l}\text { Mikroenkapsulat MSM } \\
\text { pada mi instan }\end{array}$ & 10,96 & 1,83 & 70 & 21,35 & $\begin{array}{l}\text { Wulandari, dkk. } \\
\text { (2015) }\end{array}$ \\
\hline Lemak bubuk & 167,71 & 27,95 & - & - & Reputra, dkk. (2015) \\
\hline Bagelen & 18,29 & 3,05 & 50 & 25,42 & Marjan, dkk. (2016) \\
\hline Biskuit kacang & 347,15 & 57,86 & 10 & 96,43 & $\begin{array}{l}\text { Robiyansyah, dkk. } \\
\text { (2017) }\end{array}$ \\
\hline $\begin{array}{l}\text { Cookies mocaf dan } \\
\text { bekatul }\end{array}$ & 12,5 & 2,08 & 48 & 16,64 & Dwinova (2017) \\
\hline Roti manis & 110,75 & 18,46 & 20 & 61,53 & Hasibuan, dkk. \\
\hline Donat & 23,5 & 3,92 & 20 & 13,07 & (2018) \\
\hline Bolu gulung & 120 & 20 & 20 & 66,67 & \\
\hline $\begin{array}{l}\text { Minyak bumbu mie } \\
\text { ayam }\end{array}$ & - & 141,37 & - & 23,56 & $\begin{array}{l}\text { Agustina, dkk. } \\
(2018)\end{array}$ \\
\hline Saus siomay & - & 6,5 & 50 & 54,17 & $\begin{array}{l}\text { Budiyanto, dkk. } \\
\text { (2019) }\end{array}$ \\
\hline Roti kering & 36 & 18 & 10 & 30 & Harianti (2019) \\
\hline
\end{tabular}

strategi fortifikasi sebagai langkah yang efektif.

Selain pada produk pangan olahan, fortifikasi minyak sawit juga dapat diaplikasikan pada produk minuman. Fortifikasi MSM pada produk minuman yang sudah pernah diteliti di Indonesia yaitu pada produk susu bubuk rekombinasi (Marsono, dkk., 2007). Sifat MSM yang larut lemak menjadi kendala utama dalam aplikasinya pada produk minuman. Salah satu alternatif aplikasi MSM dalam produk minuman adalah berupa produk emulsi, seperti produk nanoemulsi minyak sawit ready to drink yang diteliti Muchtadi, dkk. (2015).

\subsection{Aplikasi MSM sebagai Suplemen Kesehatan}

Penelitian tentang pemanfaatan MSM tidak hanya digunakan sebagai bahan fortifikan saja, melainkan juga sebagai suplemen. Hal tersebut didasari oleh pernyataan Dong, dkk. (2017) yaitu pemberian MSM menghasilkan efek yang hampir menyerupai suplemen vitamin $A$ sehingga potensial menjadi suplemen yang efektif, kuat, dan solutif untuk mencegah atau mengurangi KVA di seluruh dunia. Desain produk suplemen lokal kaya vitamin atau provitamin A dapat menjadi salah satu model intervensi vitamin A selain dengan cara fortifikasi dan diversifikasi diet. Pengolahan MSM menjadi minuman emulsi adalah salah satu alternatif untuk menjadikan MSM sebagai suplemen vitamin A

Beberapa penelitian terkait dengan suplementasi MSM, yaitu asupan minuman suplementasi MSM sebanyak $8 \mathrm{~mL}$ sehari selama seminggu, dapat mengurangi risiko anemia pada wanita hamil (Radhika, dkk., 2003). Lietz, dkk. (2001) melaporkan bahwa MSM dapat digunakan sebagai suplemen untuk meningkatkan konsentrasi alfa dan beta karoten dalam ASI. Desain produk suplemen berupa emulsi labu dan MSM memiliki kandungan trans beta karoten sebesar 141,65 $\pm 0,47 \mathrm{mg} / \mathrm{L}$ atau setara dengan aktivitas vitamin A 236,67 IU. Dosis penggunaan untuk dewasa, ibu melahirkan dan ibu menyusui adalah maksimal $15 \mathrm{~mL}$ per konsumsi, sementara dosis untuk anak-anak adalah maksimal $5 \mathrm{~mL}$ per konsumsi. Perhitungan dosis dilakukan dengan asumsi produk akan dikonsumsi sebanyak tiga kali per hari (Rahmadi, dkk., 2016). 
Berdasarkan kedua strategi yang telah diuraikan, yaitu MSM yang diaplikasikan sebagai bahan fortifikan, maupun MSM sebagai suplemen kesehatan, keduanya merupakan strategi yang potensial untuk dikembangkan di Indonesia. Kedua strategi tersebut relatif mudah dilakukan karena diaplikasikan pada produk yang sering dikonsumsi sehari-hari dan cakupan aplikasi produknya sangat luas, baik dari jenis makanan maupun minuman. Aplikasi berbagai jenis produk pangan fortifikasi MSM tidak hanya mencakup kelompok usia anakanak dan balita saja, namun juga kelompok usia lainnya. Selain itu, produk yang dihasilkan juga lebih ekonomis karena bahan baku MSM adalah minyak sawit, yang ketersediaannya sangat melimpah di Indonesia. Kendati demikian, masih terdapat kendala yang perlu dihadapi dalam upaya pemanfaatan MSM ini, yaitu masih diperlukannya sosialisasi dan penyediaan MSM secara komersial. Ketersediaan MSM di pasar dengan harga terjangkau perlu diupayakan sebagai salah satu langkah penanggulangan masalah KVA melalui pemanfaatan karotenoid MSM di berbagai produk pangan.

\section{KESIMPULAN}

Minyak sawit merah (MSM) mengandung kadar karotenoid yang tinggi, khususnya beta karoten yang berperan sebagai provitamin A alami. Jumlah produksi minyak sawit yang melimpah di Indonesia dengan efektivitas provitamin A-nya menjadikan pemanfaatan MSM sangat potensial untuk dikembangkan sebagai upaya penanggulangan kekurangan vitamin A (KVA). Strategi pemanfaatan MSM untuk menanggulangi masalah KVA dapat dilakukan dengan menjadikan MSM sebagai bahan fortifikan produk pangan atau sebagai suplemen kesehatan. Fortifikasi MSM pada berbagai produk pangan komersial yang umum dikonsumsi sehari-hari akan mampu mendukung pemenuhan asupan vitamin $\mathrm{A}$ di berbagai kelompok usia dan status ekonomi yang berbeda. MSM juga dapat dijadikan sebagai suplemen kesehatan berbasis pangan nabati yang efektif untuk mencegah atau mengurangi KVA.

\section{DAFTAR PUSTAKA}

Adawiah, R. 2012. All about KVA (Kurang Vitamin A). https://www.kompasiana.com/ rabiatuladaw iah/551110aea33311c539ba954f/all-about-kvakurang-vitamin-a [diakses 12 Oktober 2019].

Agustina, L., Budiyanto, dan T. Tutuarima. 2018. Substitusi RPO pada Bumbu dan Penerimaan serta Potensi Fortifikasi Vitamin A melalui Mie Ayam. Jurnal Agroindustri. Vol. 8:150-158.

Andarwulan, N., D.R. Adawiyah, N. Wulandari, P. Hariyadi, R.N. Triana, A.R. Affandi, R.C. Nur, S. Tjahjadi, dan M.F. Ellen. 2014. Aplikasi Margarin Minyak Sawit Merah pada Produk Pound Cake dan Roti Manis. Prosiding Seminar Hasil PPM IPB 2014. Vol. 1:192-206.

Astuti, S.D. 2010. Formulasi dan Karakterisasi Gel Minyak Sawit (Palm Oil Gel) Kaya Karotenoid sebagai Ingredien Pangan Fungsional. Tesis. Institut Pertanian Bogor. Bogor.

Basiron, Y., B.S. Jalani, and C.K. Weng. 2000. Advances Oil Palm Research. Malaysian Palm Oil Board. Malaysia.

Badan Pengawas Obat dan Makanan. 2016. Keputusan Kepala Badan Pengawas Obat dan Makanan Republik Indonesia Nomor 9 Tahun 2016 tentang Acuan Label Gizi. Jakarta.

Budiyanto, D. Silsia, Z. Efendi, dan R. Janika. 2010. Perubahan Kandungan $\beta$-karoten, Asam Lemak Bebas, dan Bilangan Peroksida Minyak Sawit Merah selama Pemanasan. Agritech. Vol. 30. Mei:75-79.

Budiyanto, D. Silsia, dan A. Napitupulu. 2019. Alternative Fortification Vitamin A for Lactating Mother Using Siomay Sauce Enriched with Red Palm Oil. Agritropica: Journal of Agricultural Science. Vol. 2:13-25

Catanzaro, R., N. Zerbinati, U. Solimene, M. Marcellino, D. Mohania, A. Italia, A. Ayala, and F. Marotta. 2016. Beneficial Effect of Refined Red Palm Oil on Lipid Peroxidation and Monocyte Tissue Factor in HCV-Related Liver Disease: A Randomizer Controller Study. Hepatobiliary Pancreat Dis Int. Vol. 15. Apr:165-172.

Departemen Kesehatan RI. 2003. Deteksi dan Tatalaksana Kasus Xeroftalmia. Pedoman Bagi Tenaga Kesehatan. Jakarta.

Dong, S., H. Xia, F. Wang, and G. Sun. 2017. The Effect of Red Palm Oil on Vitamin A Deficiency: A Meta-Analysis of Randomized Controlled Trials. Nutrients. Vol. 9. Dec: 1281-1295.

Dwinova, N. 2017. Formulasi Cookies Berbahan Mocaf dan Bekatul dengan Penambahan Minyak Sawit Merah sebagai Pangan Fungsional bagi Lansia. Skripsi. Institut Pertanian Bogor. Bogor.

Food and Drugs Administration. 2009. Food Labeling. Food and Drugs Administration Department of Health and Human Services Subchapter 
B-Food for Human Consumption. https://www. accesdata.fda .gov [diakses 12 Oktober 2019].

Gabungan Pengusaha Kelapa Sawit Indonesia. 2020. Refleksi Industri Kelapa Sawit 2019 dan Prospek 2020. https://gapki.id/news/ 16190/ refleksi-industri-kelapa-sawit 2019-danprospek-2020 [diakses 07 April 2020].

Grune, T., G. Lietz, A. Palou, A.C. Ross, W. Stahl, G. Tang, D. Thurnham, S.A. Yin, and H.K. Biesalski. 2010. $\beta$-Carotene is an Important Vitamin A Source for Humans. Journal of Nutrition. Vol. 140. Dec:2268-2285.

Harianti, R. 2019. Intervensi Roti Kering yang Diperkaya Minyak Sawit Merah untuk Pencegahan Risiko Aterosklerosis pada Pria Dewasa Dislipidemia. Disertasi. Institut Pertanian Bogor. Bogor.

Hasibuan, H.A. dan D. Siahaan. 2014. Review Standar Minyak Goreng Sawit Diperkaya Karoten Terkait Fortifikasi Vitamin A sebagai Revisi SNI 01-3741-2002. Jurnal Standarisasi. Vol. 16. Mar: 65-76.

Hasibuan, H.A., A. Akram, P. Putri, E.C. Mentari, dan B.T. Rangkuti. 2018. Pembuatan Margarin dan Baking Shortening Berbasis Minyak Sawit Merah dan Aplikasinya dalam Produk Bakery. Agritech. Vol. 38. Okt: 353-363.

Institute of Medicine. 2001. Dietary Reference Intakes for Vitamin A, Vitamin K, Arsenic, Boron, Chromium, Copper, lodine, Iron, Manganese, Molybdenum, Nickel, Silicon, Vanadium, and Zinc. Panel on Micronutrients, Food and Nutrition Board. Washington, DC.

Jati, I.R.A.P., V. Vadivel, D. Nohr, and H.K. Biesalski. 2012. Dietary Formulation to Overcome Micronutrient Deficiency Status in Indonesia. Nutrition and food Science. Vol. 42. Sept: 362370.

Kementerian Kesehatan RI. 2015. Situasi Kesehatan Anak Balita di Indonesia. Pusat Data dan Informasi Kementerian Kesehatan RI. Jakarta.

Kementerian Kesehatan RI. 2019. Peraturan Menteri Kesehatan Republik Indonesia Nomor 28 Tahun 2019 tentang Angka Kecukupan Gizi yang Dianjurkan untuk Masyarakat Indonesia. Kementerian Kesehatan RI. Jakarta.

Kementerian Perindustrian RI. 2019. Peraturan Menteri Perindustrian Republik Indonesia Nomor 46 Tahun 2019 tentang Pemberlakuan Standar Nasional Indonesia Minyak Goreng Sawit secara Wajib. Kementerian Perindustrian RI. Jakarta.

Koushki, M., M. Nahidi, and F. Cheraghali. 2015. Physico-Chemical Properties, Fatty Acid Profile and Nutritional in Palm Oil. Journal of
Paramedical Sciences. Vol. 6. Aug:117-134.

Lietz, G., C.J. Henry, G. Mulokozi, J.K. Mugyabuso, A. Ballart, G.D. Ndossi, W. Lorri, and A. Tomkins. 2001. Comparison of the Effects of Sumplemental Red Palm Oil and Sunfower Oil on Maternal Vitamin A Status. The American Journal of Clinical Nutrition. Vol. 74. Oct: 501-509.

Loganathan, R., K.M. Subramaniam, A.K. Radhakrishnan, Y.M. Choo, and K.T. 2017. Health-Promoting Effects of Red Palm Oil: Evidence from Animal and Human Studies. Nutrition Reviews. Vol. 75. Feb: 98-113.

Manorama, K. 2014. Potential Use of Red Palm Oil in Combating Vitamin A Deficiency in India. Indian Journal of Community Health. Vol. 26. Nov: 45-53.

Martianto, D., N. Andarwulan, dan Y. Putranda. 2018. Retensi Fortifikan Vitamin A dan $\beta$-Karoten dalam Minyak Goreng Sawit selama Pemasakan. Jurnal Teknologi dan Industri Pangan. Vol. 29. Agus: 127-136.

Marjan, A.Q., S.A. Marliyati, dan I. Ekayanti. 2016. Pengembangan Produk Pangan dengan Subtitusi RPO sebagai Alternatif Pangan Fungsional Tinggi Beta Karoten. Jurnal Pangan dan Gizi. Vol. 11. Jul: 91-98.

Marliyati, S.A., Hardinsyah, dan N. Rucita. 2010. Pemanfaatan RPO (Red Palm Oil) sebagai Sumber Provitamin A Alami pada Produk Mi Instan untuk Anak Balita. Jurnal Gizi dan Pangan. Vol. 5. Mar: 31-38.

Marsono, Y., A. Murdiati, dan S. Naruki. 2007. Substitusi Minyak Jagung dengan Minyak Sawit Merah dalam Produksi Susu Bubuk Rekombinasi: Pengaruhnya pada Sifat Fisik dan Gizi. Jurnal Teknologi Pangan dan Gizi. Vol. 6. Okt: 41-48.

Mason, J., T. Greiner, R. Shrimpton, D. Sanders, and J. Yukich. 2014. Vitamin A Policies Need Rethinking. International Journal of Epidemiology. Vol. 44. Oct: 283-292.

Muchtadi, T.R., N. Wulandari, Hunaefi, D., Darmawati, E., Andrianto, M.S., Sukmawati, Y. 2015. Prospek Industrialisasi Produk Hilir Minyak Kelapa Sawit. Prosiding Seminar Hasil-Hasil PPM IPB 2015. Vol. 1:159-180.

Nagendran, B., U.R. Unnithan, Y.M. Choo, and K. Sundram. 2000. Characteristics of Red Palm Oil, A Carotene- and Vitamin E-Rich Refined Oil for Food Uses. Food and Nutrition Bulletin. Vol. 21. Jan:189-194.

Naibaho, P.M. 1990. Penggunaan Minyak Sawit Sebagai Sumber Provitamin A Dan Dampaknya Terhadap Perkembangan Industri Minyak Sawit. Pusat Penelitian Perkebunan. Medan 
Nokkaew, R., V. Punsuvon, T. Inagaki, and S. Tsuchikawa. 2019. Determination of Carotenoids and DOBI Content in Crude Palm Oil by Spectroscopy Techniques: Comparison of Raman and FT-NIR Spectroscopy. International Journal of GEOMATE. Vol. 16. Mar:92-98.

Palmer, A.C., K.P. West, N. Dalmiya, and W. Schultink. 2012. The Use and Interpretation of Serum Retinol Distributions in Evaluating The Public Health Impact of Vitamin A Programmes. Public Health Nutrition. Vol. 15. March: 1201-1215.

Radhika, M.S., P. Bhaskaram, N. Balakrlshna, and B.A. Ramalakshmi. 2003. RPO Supplementation: A Feasible Diet-Based Approach to Improve the Vitamin A Status of Pregnant Women and Their Infant. Food and Nutrition Bulletin. Vol. 24. Jun: 208-217.

Rahmadi, A., llyas, S. Agustin, M. Rohmah, B. Saragih. 2016. Desain Produk Suplemen Labu dan Minyak Sawit Merah untuk Pencegahan Kekurangan Vitamin A. Indonesian Scholars Journal-Insight: 60-70.

Reputra, J., P. Hariyadi, dan N. Andarwulan. 2015. Penggunaan Minyak Sawit Merah untuk Pembuatan Lemak Bubuk Kaya $\beta$-karoten melalui Proses Pendinginan Semprot. Agritech. Vol. 35. Nov: 406-413.

Riset Kesehatan Dasar. 2018. Hasil Utama Riskesdas 2018. Kementerian Kesehatan RI: Badan Penelitian dan Pengembangan Kesehatan. Jakarta.

Rice, A.L. and J.B. Burns. 2010. Moving from Efficacy to Effectiveness: Red Palm Oil's Role in Preventing Vitamin A Deficiency. Journal of The American College of Nutrition. Vol. 29. Jun: 302-313.

Robiyansyah, A.S. Zuidar, dan S. Hidayati. 2017. Pemanfaatan Minyak Sawit Merah dalam Pembuatan Biskuit Kacang Kaya Beta Karoten. Jurnal Teknologi Industri dan Hasil Pertanian. Vol. 22. Mar: 11-20.

School Health and Nutrition. 2020. Vitamin A. http:// www.schoolsandhealth.org/Pages/vitamina. aspx\# [diakses 24 Juli 2020].

Sluijs, I., E. Cadier, J.W. Beulens, A.D.L. Van der, A.M. Spijkerman, and Y.T. Van der Schouw. 2015. Dietary Intake of Carotenoids and Risk of Type 2 Diabetes. Nutrition Metabolism and Cardiovascular Diseases. Vol. 25. Dec: 376381.

Sommer, A., I. Tarwojo, G. Hussaini, and D. Susanto. 1983. Mortality in Children with Mild Vitamin A Deficiency. The Lancet. Vol. 2. Sep: 585-588.

Sommerburg, O., S.D. Spirt, A. Mattern, C. Joachim, C.D. Langhans, K. Nesaretnam, W. Siems, W. Stahl, and M.A. Mall. 2015. Supplementation with Red Palm Oil Increases $\beta$-Carotene and Vitamin A Blood Levels in Patients with Cystic Fibrosis. Mediators of Inflammation. Vol. 6. Jan: $1-7$.

Souganidis, E., A. Laillou, M. Leyvraz, and R. Moench-Pfanner. 2013. A Comparison of Retinyl Palmitate and Red Palm Oil $\beta$-Carotene as Strategies to Address Vitamin A Deficiency. Nutrients. Vol. 5. Aug: 3257-32711.

Tsaqqofa, S. 2010. Meninjau Kebijakan Fortifikasi Vitamin A pada Minyak Goreng 2011. https:// www.kompasiana.com/sarahaeyo/55001eea81 33117c1bfa7200/meninjau-kebijakan-fortifikasivitamin-a-pada-minyak-goreng-2011 [diakses 12 Oktober 2019].

United Nations International Children's Emergency Fund. 2019. Vitamin A. https://data.unicef. org/resources/vitamin-a-coverage [diakses 12 Oktober 2019].

Word Health Organization. 2009. Global Prevalence of Vitamin A Deficiency in Populations at Risk 1995-2005. WHO Global Database on Vitamin A Deficiency. Gevana, Switzerland.

World Health Organization. 2011. Guideline: Vitamin A Supplementation in Infants and Children 6-59 Months of Age. WHO Library Cataloguing in Publication Data. Gevana, Switzerland.

Wulandari, N., S. Angka, D.R. Adawiyah, dan N.S. Palupi. 2015. Aplikasi Mikroenkapsulat Minyak Sawit Merah pada Mi Instan. Jurnal Mutu Pangan. Vol. 2:41-49.

Yuliasari, S., D. Fardiaz, N. Andarwulan, dan S. Yuliani. 2014. Karakteristik Nanoemulsi Minyak Sawit Merah yang Diperkaya Beta Karoten. Jurnal Littri. Vol. 20. Sept: 111-121.

\section{BIODATA PENULIS:}

Risnawati Dwi Maryuningsih dilahirkan di Jakarta, 21 Juni 1994. Penulis menyelesaikan pendidikan S1 IImu dan Teknologi Pangan, Universitas Jenderal Soedirman tahun 2016 dan sekarang sedang melanjutkan studi di IImu Pangan, Universitas IPB.

Budi Nurtama dilahirkan di Yogyakarta, 15 April 1959. Penulis menyelesaikan pendidikan S1 Teknik Pertanian, Universitas IPB tahun 1982, S2 Food Science, Guelph University, Kanada tahun 1991 dan S3 Food Science, National Pitung University, Taiwan tahun 2010.

Nur Wulandari dilahirkan di Bandung, 3 Oktober 1974. Penulis menyelesaikan pendidikan S1 Teknologi Pangan, Universitas IPB tahun 1998, S2 Ilmu Pangan, Universitas IPB tahun 2008 dan S3 IImu Pangan, Universitas IPB tahun 2012. 


\section{PETUNJUK PENULISAN "PANGAN"}

\section{ISI DAN KRITERIA UMUM}

Pangan, terbit 3 (tiga) kali setahun, adalah jurnal nasional terakreditasi dengan peringkat 2 oleh Kementerian Riset, Teknologi, dan Pendidikan Tinggi Rl nomor 28/E/KPT/2019. Jurnal Pangan mempublikasikan artikel ilmiah (research article), kajian (review) tentang pangan, baik sains maupun terapan dan tulisan lainnya yang berkaitan dengan pangan. Redaksi menerima tulisan dari semua bidang ilmu yang terkait dengan komoditi pangan dari segala sumber. Komoditi pangan yang dimaksud adalah beras, jagung, kedelai, gula, minyak goreng, tepung terigu, bawang merah/putih, cabe daging sapi, daging ayam ras, dan telur ayam. Ruang lingkup penulisan meliputi aspek-aspek yang berkaitan dengan produksi, pengolahan, penyimpanan, transportasi, pemasaran, perdagangan, konsumsi dan gizi, sarana, teknologi, jasa, pendanaan, dan kebijakan. Tulisan yang dikirim ke redaksi adalah tulisan yang belum pernah dipublikasikan atau tidak sedang diajukan pada majalah/jurnal lain.

Tulisan ditulis dalam bahasa Indonesia sesuai kaidah bahasa yang digunakan. Tulisan harus selalu dilengkapi dengan Abstrak dwibahasa (Indonesia dan bahasa Inggris). Tulisan yang diajukan harus disertai biodata penulis yang berisi nama lengkap penulis, tempat tanggal lahir, jabatan penulis, instansi penulis beserta alamatnya, riwayat pendidikan penulis, dan alamat email. Tulisan yang isi dan formatnya tidak sesuai dengan pedoman penulisan "Pangan" akan ditolak oleh Redaksi dan Redaksi tidak berkewajiban untuk mengembalikan tulisan tersebut.

\section{KATEGORI TULISAN}

Artikel Ilmiah (Research Article) (sekitar 8-20 halaman jurnal). Artikel yang diajukan berisi kemajuan utama (major advance) yang merupakan original research findings. Artikel ilmiah harus mencakup abstrak, pandahuluan, bagianbagian dengan sub-judul (sub-heading) ringkas, dan maksimum 40 referensi. Materi dan metode harus dimasukkan guna menunjang material online, yang juga harus memasukkan informasi lain yang dibutuhkan untuk mendukung kesimpulan.

Kajian (Review) (sekitar 8-20 halaman jurnal) mendeskripsikan perkembangan baru kesignifikanan interdisiplin dan menyorot pertanyaan-pertanyaan yang belum teresolusi serta arahnya di masa mendatang. Semua review akan melalui proses pengkajian oleh peer-reviewer. Review yang dikirim harus memuat abstrak, pandahuluan, bagian-bagian dengan sub-judul (sub-heading) ringkas, dan maksimum 40 referensi.

Tulisan selain artikel ilmiah dan kajian yang berkaitan dengan pangan (sekitar 2-8 halaman jurnal) menyajikan hal-hal seperti kebijakan-kebijakan baru dan penting dengan kesignifikanan yang luas, baik skala nasional maupun internasional, komentar terhadap masalah pangan, diseminasi undang-undang, Peraturan Pemerintah, Inpres, Keppres, bedah buku, wawancara.

Tulisan yang dikirim diprioritaskan yang berskala nasional dan internasional.

\section{SELEKSI NASKAH}

Pertama, Proses pengajuan dan review tulisan dilakukan baik lewat hardcopy maupun softcopy.

Kedua, Tulisan yang dipertimbangkan untuk di review adalah yang memenuhi persyaratan penulisan sesuai petunjuk penulisan.

Ketiga, Semua tulisan yang telah memenuhi tata cara penulisan akan diberikan penilaian tentang kepantasan pemuatannya oleh Dewan Editor (Board of Reviewing Editors).

Keempat, Tulisan yang layak diterbitkan akan diproses lebih lanjut. Waktu yang dibutuhkan untuk proses penelaahan oleh dewan editor dan mitra bestari paling lama 8 minggu setelah tulisan diterima.

Kelima, Tulisan yang tidak dapat diterbitkan akan diberitahukan kepada penulis via e-mail.

\section{FORMAT PENULISAN}

Umum. Seluruh bagian dari tulisan termasuk judul, abstrak, judul tabel dan gambar, catatan kaki dan daftar acuan diketik satu spasi pada electronic file dan print out dalam kertas ukuran A4. Pengetikan dilakukan dengan menggunakan huruf (font) Arial berukuran 11 point dengan jarak spasi 1 (spasi) dan jarak antar paragraph 6 point.

Setiap halaman diberi nomor serta secara berurutan termasuk halaman gambar dan tabel. Hasil penelitian atau ulas balik/ tinjauan ditulis minimal 8 lembar dan maksimal 20 lembar, termasuk gambar dan tabel. Selanjutnya susunan naskah dibuat sebagai berikut :

Tulisan ilmiah dari hasil penelitian harus mempunyai struktur sebagai berikut :

Judul (Titles) makalah ilmiah bahan publikasi hasil riset semestinya menonjolkan fenomena yang diteliti (objek 
riset). Judul bukan metode dan juga bukan kegiatan (proyek). Judul tidak tidak terlalu panjang dimana fungsi aneka kata kunci terkait jelas. Judul dibuat dalam dua bahasa yaitu bahasa Indonesia dan bahasa Inggris serta ditulis dengan jenis huruf Times New Roman ukuran 16 point. Pada bagian bawah judul dicantumkan identitas penulis yang memuat nama penulis, lembaga dan alamat lembaga serta alamat e-mail.

Abstrak (abstracts) menjelaskan kepada pembaca umum kenapa riset dilakukan dan kenapa hasilnya penting. Abstrak tidak lebih dari 200 kata, mengemukakan poin-poin utama tulisan dan outline hasil atau kesimpulan. Abstrak ditulis dalam satu paragraf dan mengandung poin-poin sebagai berikut : (i) Alasan riset dilakukan (the purpose and objective of the study; the central question); (ii) Pernyataan singkat apa yang telah dilakukan (what was done; the method); (iii) Pernyataan singkat apa yang telah ditemukan (what was found; the result); dan (iv) Pernyataan singkat tentang kesimpulan (what was concluded; discussion). Abstrak harus ditulis dalam dwibahasa (Indonesia dan Inggris). Abstrak juga harus disertai dengan kata kunci (keywords) antara 3-6 kata dan ditulis dalam dwibahasa.

Pendahuluan, berisi penjelasan padat dan ringkas tentang latar belakang penelitian, tujuan penulisan atau menggambarkan apa yang akan disampaikan dalam tulisan secara jelas namun tidak terlalu berlebihan. Pendahuluan harus didukung oleh sumber pustaka yang memadai khususnya pustaka primer dan jelas menunjukkan perkembangan dari materi penulisan.

Metodologi berisikan disain penelitian yang digunakan, populasi, sampel, sumber data, instrumen, analisis dan teknik analisis yang digunakan.

Hasil dan pembahasan Hasil adalah temuan penelitian yang disajikan apa adanya tanpa pendapat penulis dan pembahasan menjelaskan dengan baik serta argumentatif tentang temuan penelitian serta relevansinya dengan penelitian terdahulu.

Kesimpulan menjawab tujuan penelitian tanpa melampauinya. Bila ada rekomendasi penelitian, dapat dimasukkan dalam subbab kesimpulan.

Daftar Pustaka, bagian ini berisi sumber rujukan yang digunakan dalam penulisan ilmiah tersebut. Ditulis dengan menggunakan sistem Chicago dan disusun menurut abjad. Daftar pustaka ditulis dengan menggunakan jenis huruf arial ukuran 10 point.

Biodata Penulis berisi nama lengkap penulis, tempat tanggal lahir, jabatan dan instansi penulis, riwayat pendidikan serta alamat email. Biodata penulis ditulis dengan menggunakan jenis huruf arial ukuran 10 point.

Tulisan ilmiah dari hasil penelitian, apabila penulis perlu menyampaikan ucapan terimakasih dapat dimasukkan dalam tulisan dan diletakkan sebelum daftar pustaka.

Tulisan ilmiah yang berbentuk kajian (bukan hasil penelitian murni) memiliki struktur seperti diatas namun tidak harus mencantumkan metode penelitian dalam subbab tersendiri.

Tulisan lain yang berkaitan dengan pangan, struktur penulisannya disesuaikan dengan isi.

\section{Contoh Penulisan Daftar Pustaka :}

\section{Buku}

Sawit, M. Husein dan Erna Maria Lakollo. 2007. Rice Import Surge in Indonesia. Bogor : ICASEPS and AAI.

\section{Terjemahan}

Kotler, Philip. 1997. Manajemen pemasaran : Analisis, perencanaan, implementasi (Hendra Teguh \& Ronny Antonius Rusli, Penerjemah.). Jakarta: Prenhallindo.

\section{Seminar}

Notohadiprawiro, T. dan J.E. Louhenapessy. 1992. Potensi Sagu Dalam Penganekaragaman Bahan Pangan Pokok Ditinjau Dari Persyaratan Lahan. Makalah disampaikan pada Simposium Sagu Nasional. 12-13 Oktober. Ambon.

\section{Bab dalam Buku}

Suismono dan Suyanti. 2008. Sukun sebagai Sumber Pangan Pokok Harapan dalam Penganekaragaman Konsumsi Pangan. Di dalam Wisnu Broto dan S. Prabawati (eds) Teknologi Pengolahan untuk Penganekaragaman Konsumsi Pangan. BB Pascapanen.

\section{Artikel Jurnal}

Morthy S.N. 1983. Effect of Some Physical and Chemical Treatment on Cassava Flour Quality. Journal of Food Science and Technology. Vol. 20. Nov/Dec : 302-305. 


\section{Surat Kabar}

Santoso, D. A.. 2009. Kedaulatan vs Ketahanan Pangan. Kompas, 13 Januari 2009.

\section{Prosiding}

Manurung, S.O. dan S. Partohardjono. 1984. Prospek Penggunaan Sitozim Sebagai Komponen Teknologi Untuk Meningkatkan Hasil Padi. Prosiding Simposium Padi. Bogor : Puslitbangtan.

\section{Publikasi Dokumen Pemerintah}

Biro Pusat Statistik. 1990. Struktur Ongkos Usaha Tani Padi dan palawija. Jakarta : BPS.

\section{Skripsi/tesis/disertasi}

Brotodjojo, R.R.R. 2007. Host searching behaviour of a generalist egg parasitoid - responses to alternative hosts with different physical characteristics. PhD Thesis at The University of Queensland, $180 \mathrm{~h}$.

\section{Situs Web}

Khomsan A. 2006. Beras dan Diversifikasi Pangan. http://kompas.com/kompas-cetak/0612/21/opini/3190395.htm [diakses 09 Feb 2008]

Tabel harus disusun secara jelas dan sesingkat mungkin. Penyusunan tabel harus memperhatikan hal-hal sebagai berikut : (i) tabel harus dapat dibaca dan dipahami secara tersendiri tanpa mengacu atau mengaitkannya dengan uraian pada teks, (ii) judul tabel harus dapat menggambarkan pemahaman terhadap isi tabel, (iii) pencantuman tabel sedekat mungkin dengan uraiannya pada teks, bila letak tabel berbeda halaman misalnya dua atau tiga halaman setelah uraian pada teks maka uraian dalam teks harus mencantumkan nomor tabel, dan bila agak jauh (melebihi tiga halaman) maka cantumkanlah nomor tabel dan halaman tabel. Penyusunan tabel harus memenuhi beberapa persyaratan yaitu : (i) Tabel dicantumkan pada kertasa teks dan simetris terhadap ruang ketikan kiri dan kanan, (ii) Tabel diberi nomor urut dengan angka arab dan diikuti dengan judul tabel yang diletakkan simetris di atas tabel. Bila judul tabel lebih dari satu baris, maka baris kedua dan selanjutnya dimulai sejajar dengan huruf pertama judul tabel pada baris pertama, (iii) Tabel yang terdiri kurang dari satu halaman dapat diletakkan langsung dibawah teks pada naskah yang bersangkutan, dan bila lebih dari satu halaman teks dapat dilakukan dengan dilanjutkan pada halaman berikutnya dengan mencantumkan nomor tabel dan kata lanjutan tanpa disebutkan judul tabelnya atau diletakkan pada lampiran, (iv) tabel yang memuat kutipan dari data sekunder harus mencantumkan sumber kutipan pada bagian bawah kiri sesudah tabel, (v) tabel dibuat satu dimensi tanpa garis batas yang memisahkan antar kolom.

Gambar yang disajikan harus berkaitan dengan uraian pada naskah. Gambar dapat dibentuk bagan/diagram, grafik, peta maupun foto. Penyusunan gambar harus memperhatikan beberapa hal seperti halnya tabel, namun judul gambar diletakkan dibagian bawah gambar tersebut.

\section{PENGIRIMAN}

Penulis dapat mengirimkan tulisan dalam bentuk softcopy melalui email ke : redaksi@jurnalpangan.com

Penulis juga dapat mengirimkan tulisan dalam bentuk compact disk(CD) yang harus disiapkan dengan Program Microsoft Word dan dikirim ke :

\section{Redaksi Jurnal Pangan}

Perum BULOG, Divisi Renstra, Riset, dan Manrisk, Lt 11 Gedung BULOG 1

Jl. Gatot Subroto Kav 49, Jakarta Selatan, 12950.

Telp . (021) 5252209 ext. 2123, 2131, 2103

Pengiriman naskah harus disertai dengan surat resmi dari penulis penanggung jawab/korespondensi (corresponding outhor), yang harus berisikan dengan nama jelas penulis korespondensi, alamat lengkap untuk surat menyurat, nomor telephone dan faks, serta alamat email dan telephon genggam jika memiliki. Penulis korespondensi bertanggungjawab atas isi naskah dan legalitas pengiriman naskah yang bersangkutan. Naskah juga sudah harus diketahui dan disetujui oleh seluruh anggota penulis dengan pernyataan tertulis. 
Halaman ini sengaja dikosongkan 